\title{
Timing of blooms, algal food quality and Calanus glacialis reproduction and growth in a changing Arctic
}

\author{
JANNE E. SØREIDE*, EVA LEU†, JØRGEN BERGE*, MARTIN GRAEVE $\ddagger$ and \\ STIG FALK-PETERSEN† \\ *The University Centre in Svalbard, PO Box 156, N-9171 Longyearbyen, Norway, †Norwegian Polar Institute, N-9296 Troms $\varnothing$, \\ Norway, $\ddagger$ Alfred-Wegner-Institute für Polar-und Meeresforschung, Am Handelshafen 12, 27570 Bremerhaven, Germany
}

\begin{abstract}
The Arctic bloom consists of two distinct categories of primary producers, ice algae growing within and on the underside of the sea ice, and phytoplankton growing in open waters. Long chain omega-3 fatty acids, a subgroup of polyunsaturated fatty acids (PUFAs) produced exclusively by these algae, are essential to all marine organisms for successful reproduction, growth, and development. During an extensive field study in the Arctic shelf seas, we followed the seasonal biomass development of ice algae and phytoplankton and their food quality in terms of their relative PUFA content. The first PUFA-peak occurred in late April during solid ice cover at the onset of the ice algal bloom, and the second PUFA-peak occurred in early July just after the ice break-up at the onset of the phytoplankton bloom. The reproduction and growth of the key Arctic grazer Calanus glacialis perfectly coincided with these two bloom events. Females of $C$. glacialis utilized the high-quality ice algal bloom to fuel early maturation and reproduction, whereas the resulting offspring had access to ample high-quality food during the phytoplankton bloom 2 months later. Reduction in sea ice thickness and coverage area will alter the current primary production regime due to earlier ice break-up and onset of the phytoplankton bloom. A potential mismatch between the two primary production peaks of high-quality food and the reproductive cycle of key Arctic grazers may have negative consequences for the entire lipid-driven Arctic marine ecosystem.
\end{abstract}

Keywords: Calanus glacialis, climate change, food quality, ice algae, lipids, mismatch-hypothesis, phytoplankton, PUFAs

Received 19 August 2009 and accepted 20 November 2009

\section{Introduction}

Although the dramatic loss of Arctic sea ice during the last decade is indisputable (Smetacek \& Nicol, 2005; Stroeve et al., 2007; Comiso et al., 2008), the consequences of this loss on key biological processes remain largely unknown. Of the studies addressing potential impacts of climate change on polar marine ecosystems, few have focused on the biochemical aspects of trophic interactions (e.g., food quality and transfer) (but see (Falk-Petersen et al., 2007; Kaartvedt, 2008).

Sea ice plays a dual role for primary production in polar seas (Smetacek \& Nicol, 2005), both providing a habitat for ice algae and regulating the available light for primary production. Ice algae begin growing in low light levels in March and continue growing until their sea ice substratum melts (Hegseth, 1998). In contrast, phytoplankton production starts after the ice break-up, giving a temporal discontinuity between sea ice and open-water production. As the window of opportunity for primary production becomes narrower at higher latitudes, the timing and availability of essential

Correspondence: Janne E. Søreide, tel. + 47 79023300,

fax + 47 79023301, e-mail: Janne.Soreide@unis.no omega-3 fatty acids become increasingly crucial for all marine organisms. The long-chain eicosapentaenoic acid (EPA) and docosahexaenoic acid (DHA) are omega-3 fatty acids produced exclusively by marine algae. These polyunsaturated fatty acids (PUFAs) play a key role in reproduction, growth, and physiology for all organisms in marine ecosystems (Ackman, 1989), as well as for human health (Riediger et al., 2009). The importance of omega-3 fatty acids for copepod egg production, egg hatching, and zooplankton growth has been well documented in field (Pond et al., 1996; Swadling et al., 2000; Jonasdottir et al., 2005) and experimental studies (Breteler et al., 2005; Jonasdottir et al., 2009), and has furthermore been proven to be essential for proper fish development (Watanabe et al., 1983).

Among the zooplankton in the arctic shelf seas, the arctic grazer Calanus glacialis accounts for up to $80 \%$ of the biomass (Tremblay et al., 2006; Blachowiak-Samolyk et al., 2008; Søreide et al., 2008) and plays a key role in the pelagic lipid-based arctic food web (Falk-Petersen et al., 1990). C. glacialis accumulates essential PUFAs from its algal diet, and converts the low-energy carbohydrates and proteins in algae into high-energy wax ester lipids (Lee et al., 2006; Falk-Petersen et al., 2009). These lipids make it an extremely energy-rich food 
( $>70 \%$ lipids of dry weight) for higher trophic levels (Falk-Petersen et al., 1990).

C. glacialis has a 1-3 year life cycle, depending on the temperature and food regime. The life-cycle includes six nauplii and six copepodite stages that follow a pronounced seasonal migration pattern. C. glacialis develops through the various stages mainly during summer. In autumn, it accumulates lipids before it descends towards the deep and enters a diapause to survive the long and dark food-poor winter. The main overwintering stages are copepodite stage IV (CIV) and V (CV) (Falk-Petersen et al., 2009). Overwintering CV individuals develop into females in mid-winter and ascend to surface waters in spring to feed and reproduce (Kosobokova, 1999). The evolutionary success of $C$. glacialis depends on its ability to synchronize its seasonal migration, reproduction, and growth to the primary production regime in Arctic shelf seas (Falk-Petersen et al., 2009). As sea ice becomes thinner and has less coverage, the underwater light climate will change significantly (Tremblay et al., 2006; Pabi et al., 2008). This change will alter the onset, duration, and magnitude of the sea ice algal and phytoplankton blooms. Because the peak growing season for ice algae is confined to consolidated ice, the qualitative and quantitative importance of sea ice algae for the development of key Arctic grazers remain poorly studied.

To predict ecological consequences of climate change on the algal blooms and PUFA production, we carried out an extensive field study during the International Polar Year (IPY, 2007) in the seasonally ice-covered Rijpfjord in northern $\left(>80^{\circ} \mathrm{N}\right)$ Svalbard. We followed the seasonal development of ice algae and phytoplankton, including biomass variation and food quality (i.e., the proportion of PUFAs) simultaneously with population development of the key grazer C. glacialis. This study aimed at unravelling the intimate coupling between the solar cycle, food quality peaks, and the onset and duration of primary and secondary production.

\section{Materials and methods}

\section{Study area}

The study was performed in 2007 in Rijpfjorden, Svalbard (Appendix S1) as part of the Norwegian IPY-project CLEOPATRA (Climate effects on planktonic food quality and trophic transfer in Arctic marginal ice zone). Rijpfjorden is a northfacing, relatively shallow fjord (max. $240 \mathrm{~m}$ deep) that opens towards the Arctic Ocean. It has a wide opening that is in direct contact with a broad shallow shelf (100-200 m deep), which extends to the shelf-break of the Polar Basin at $\sim 81^{\circ} \mathrm{N}$ (Appendix S1). Rijpfjorden is dominated by cold Arctic water masses and is covered by sea ice up to 9 months a year
(Ambrose et al., 2006; Wallace et al., 2010). The zooplankton community in Rijpfjorden is dominated by Arctic species, with C. glacialis representing up to $90 \%$ of the zooplankton biomass (Daase \& Eiane, 2007; Blachowiak-Samolyk et al., 2008).

\section{Physical data}

Temperature, salinity, and in situ fluorescence were measured at hourly intervals by a mooring placed in close vicinity of our main sampling station (Stn. SH; Appendix S2). The mooring was equipped with SBE microcats (model: 37-SM MicroCAT; SeaBird Electronics, Bellevue, WA, USA) at 27 and $205 \mathrm{~m}$ that recorded temperature, conductivity, and pressure. In addition, Vemco temperature mini loggers (Minilog12; accuracy $\pm 0.1^{\circ} \mathrm{C}$ ) were located at 3-30 m intervals between 20 and $200 \mathrm{~m}$. At $17 \mathrm{~m}$ deep, a Seapoint Chlorophyll Fluorometer (Seapoint Sensors Inc., Exeter, NH, USA) was attached to the mooring. Only approximate chlorophyll $a$ data were available from this fluorometer due to absence of suitable water samples for exact calibration, but for identifying the approximate timing of the phytoplankton bloom is was useful. Samples for exact chlorophyll a concentrations were collected at lower resolution, monthly from April to August, and in October. The mooring was deployed in September 2006 and recovered in August 2007. For more detailed information about the mooring, see Berge et al. (2009) and Wallace et al. (2010).

We measured the photosynthetically active radiation (PAR; 400-700 nm) hourly with a PAR LITE Kipp \& Zonen Quantum Sensor (Campell Scientific, Edmonton, AB, Canada), mounted $4 \mathrm{~m}$ above sea level at the Rijpfjorden field station. Sea ice thickness and snow depth were determined for all sites from which ice cores for ice algae analyses were taken.

\section{Primary producers}

Samples of primary producers were collected monthly from March to August and in October (Appendix S2). We took core samples of ice algae using a SIPRE type corer $(12.5 \mathrm{~cm}$ diameter). For each sampling spot, we took three core replicates $(50-100 \mathrm{~cm}$ apart). We sawed off the lowest part $(5-8 \mathrm{~cm})$ of the core that contained visible amounts of ice algae. This core section was protected against light exposure and immediately transported to the field station. In the field laboratory, we slowly (24-36 h) thawed the cores in the dark in $500 \mathrm{~mL}$ of GF/ F filtered seawater. After the samples were completely thawed, subsamples were filtered through precombusted GF/F-filters $\left(1 \mathrm{~h}\right.$ at $\left.450^{\circ} \mathrm{C}\right)$ to estimate the concentration of chlorophyll $a$, the total particulate carbon $(\mathrm{C})$, and the fatty acid composition of the total lipids. Pelagic algae (phytoplankton) were sampled with a $10 \mathrm{~L}$ Niskin-bottle (Ocean Test Equipment Inc., Fort Lauderdale, FL, USA) at six depths between 0 and 50 (80) $\mathrm{m}$ (Appendix S2). At each depth, samples were measured in triplicate (0.5-3 L depending on the algae concentrations) and filtered on precombusted GF/F-filters $\left(1 \mathrm{~h}\right.$ at $450{ }^{\circ} \mathrm{C}$ ) to estimate the concentration of chlorophyll $a$, the total particulate $\mathrm{C}$, and the fatty acid composition of the total lipids.

Chlorophyll $a$ concentration was determined by high-performance liquid chromatography (HPLC). The pigments were 
extracted from the filters with $1.6 \mathrm{~mL}$ methanol. The extract was sonicated for $30 \mathrm{~s}$ using a Vibra-cell sonicator (Sonics and Materials Inc., Danbury, CT, USA) equipped with a $3 \mathrm{~mm}$ diameter probe. The extraction and HPLC analysis continued according to Wright \& Jeffrey (1997), using an absorbance diodearray detector (Spectraphysics UV600LP, Newport Corp., Thermo Fisher Scientific, Waltham, MA, USA). The column was a C18 Phenomenex Ultracarb (Torrance, CA, USA) $3 \mu \mathrm{m}$ ODS (20) $(150 \times 3.20 \mathrm{~mm})$. The HPLC system was calibrated with pigment standards from DHI, Water and Environment, Denmark.

For particulate $C$ analyses, samples of $20-100 \mathrm{~mL}$ for ice algae, and $250-2000 \mathrm{~mL}$ for phytoplankton, depending on biomass density, were filtered. All filter samples were frozen $\left(-20^{\circ} \mathrm{C}\right)$ until analysis. Particulate $C$ was analyzed on a Thermo Finnigan FlashEA 1112 elemental analyser (Waltham, MA, USA).

\section{Secondary producers}

Zooplankton was sampled monthly by WP2 closing nets with a $0.225 \mathrm{~m}^{2}$ opening, vertically at four standard depths: 0-20, 20-50, 50-100, and $100 \mathrm{~m}$ bottom (Appendix S2). To gather data on Calanus copepodites and nauplii, we used WP2 nets with mesh size $200 \mu \mathrm{m}$. To estimate Calanus egg abundance, we used modified WP2 nets with mesh size $63 \mu \mathrm{m}$. In August and October, Calanus copepodites and nauplii were sampled with a multiple plankton sampler (MPS; Hydro-Bios, Kiel, Germany) consisting of five closing nets with the same opening diameter and mesh size $(200 \mu \mathrm{m})$ as the WP2 closing net. Calanus specimens were identified to the species level based on morphology and prosome lengths of individual copepodite stages (Kwasniewski et al., 2003). Eggs and nauplii were identified to Calanus genus level. Although sampling depth ranged from $130 \mathrm{~m}$ in July and October to $186 \mathrm{~m}$ in September, Calanus density (ind. $\mathrm{m}^{-2}$ ) was calculated for 0-140 $\mathrm{m}$ in all months (Appendix S2).

To estimate egg production rates, we incubated females for $24 \mathrm{~h}$ at near to in situ temperatures, obtained by placing the incubator chambers in a large cooling box filled with sea water and sea ice. Each female was placed alone in a $200 \mathrm{~mL}$ chamber with a false bottom of $500 \mu \mathrm{m}$ mesh. Incubations started within $2-3 \mathrm{~h}$ of sampling in prescreened ( $60 \mu \mathrm{m}$ mesh size) surface sea water collected from the same site as the females.

\section{Fatty acid analysis}

Fatty acids of particulate organic matter (POM) were analyzed at Unilab (Troms $\varnothing$, Norway), whereas fatty acid and fatty alcohol of C. glacialis were analyzed at Alfred-Wegner-Institute (Bremerhaven, Germany).

For POM, triplicate samples of $100-200 \mathrm{~mL}$ from each ice core and 0.5 to $3 \mathrm{~L}$ from each water depth (Niskin samples) were filtered onto precombusted glass fibre filters (GF/F). The filters were transferred to glass vials with Teflon-lined caps and $8 \mathrm{~mL}$ dichloromethane-methanol $(2: 1, \mathrm{v} / \mathrm{v})$ was added. The vials were stored at $-80^{\circ} \mathrm{C}$ until analyzed. Total lipid was extracted according to the procedure described in Folch et al. (1957). A known amount of heneicosanoic acid (21:0) was added as internal standard, and an acid-catalysed transesterification was carried out with $1 \%$ sulfuric acid in methanol (Christie, 1982). The extract was then cleaned using a silica column (Christie, 1982). The relative composition of the fatty acid methyl esters (FAME) was determined in an Agilent 6890 N (Agilent Technologies Deutschland GmbH \& Co. KG, Waldbronn, Germany) gas chromatograph, equipped with a fused silica, wall-coated capillary column $(50 \mathrm{~m} \times 0.25 \mathrm{~mm}$ i.d., Varian Select FAME, Agilent Technologies Deutschland GmbH \& Co. KG) with an oven thermal gradient from an initial 60 to $150{ }^{\circ} \mathrm{C}$ at $30^{\circ} \mathrm{C} \mathrm{min}^{-1}$, and then to a final temperature of $230^{\circ} \mathrm{C}$ at $1.5^{\circ} \mathrm{C} \mathrm{min}{ }^{-1}$. Individual components were identified by comparison with two known standards and were quantified using HPChemStation software (Hewlett-Packard, Agilent Technologies Deutschland GmbH \& Co. KG).

For Calanus, 10-30 individuals were pooled and transferred to glass vials with Teflon-lined caps and $8 \mathrm{~mL}$ dichloromethanemethanol $(2: 1, \mathrm{v} / \mathrm{v})$ was added. These vials were stored at $-80^{\circ} \mathrm{C}$ until analyzed. Specimens from two discrete layers, the surface $(0-50 \mathrm{~m})$ and bottom layer $(>100 \mathrm{~m})$, were analyzed separately. Calanus specimens were homogenized and lipids were extracted according to Folch et al. (1957). Methyl esters of fatty acids and free fatty alcohols were prepared by transesterification of the lipid extract with 3\% concentrated sulfuric acid in methanol for $4 \mathrm{~h}$ at $80^{\circ} \mathrm{C}$ under nitrogen atmosphere. FAME and free alcohols were then simultaneously analyzed with a gas liquid chromatograph (HP 6890N, Agilent Technologies Deutschland $\mathrm{GmbH} \& \mathrm{Co} . \mathrm{KG}$ ) on a $30 \mathrm{~m} \times 0.25 \mathrm{~mm}$ i.d. wall-coated open tubular column (film thickness: $0.25 \mu \mathrm{m}$; liquid phase: DBFFAP), equipped with split/splitless injector $\left(250{ }^{\circ} \mathrm{C}\right)$ and flame ionization detector $\left(280^{\circ} \mathrm{C}\right)$ using temperature programming as described above. Fatty acids and fatty alcohols were quantified with an internal 19:0 fatty acid standard added to the sample before the extraction. Individual components were identified by comparisons to standards or, if necessary, by additional GC-mass spectrometry runs. The samples were quantified using ChemStation software (Agilent, Agilent Technologies Deutschland $\mathrm{GmbH}$ \& Co. KG). Total lipid composition was calculated as sum of total fatty acids and fatty alcohols.

All identified PUFAs and omega-3 fatty acids (Appendix S4) were included when calculating the proportions of PUFAs and omega-3 fatty acids in algae and C. glacialis.

\section{Statistical analyses}

Statistical tests were performed using STATISTICA 7.0 (StatSoft Inc., Tulsa, OK, USA): $t$-tests were used when comparing two independent groups, and one-way ANOVA followed by the post hoc tests Tukey's honestly significantly different (HSD) and unequal Tukey's HSD were used when comparing multiple groups with similar or unequal number of replicates per group, respectively (Winer et al., 1991). If the variance between independent groups was unequal (i.e., Levene's T-test $P \leq 0.05$ ), we used the MannWhitney $U$-test (MWU-test) and Kruskal-Wallis multiple comparisons of mean ranks for all groups (Siegel \& Castellan, 1988). The significance level was set to $P \leq 0.05$ in all tests.

\section{Results}

\section{Physical properties: hydrography, sea ice, and light}

Rijpfjorden froze solid February 2, 2007 (J. Berge, personal observations). During the ice covered period from 
February to end of June there was a cold $\left(-1.8^{\circ} \mathrm{C}\right)$ homogenous water mass from surface to bottom (Fig. 1). The sea ice thickness was on average $0.5 \mathrm{~m}$ in March, and around $1 \mathrm{~m}$ thick from April to June (mean $0.9 \pm 0.1 \mathrm{~m})$. By the end of June, the sea ice started to break up, and on 12 July, the fjord was ice free (J. E. Søreide, personal observations). In Rijpfjorden $\left(80.27^{\circ} \mathrm{N}\right.$ and $22.29^{\circ} \mathrm{E}$ ), the sun appeared for the first time in late February (22 February) (http://www.esrl.noaa.gov/ gmd/grad/solcalc/). The mean daily light intensities increased rapidly the following months (Appendix S3), and the midnight sun appeared from 11 April to 31 August. The 4 months of the long polar night period began when the sun disappeared on 21 October.

\section{Primary producers: ice algae and phytoplankton}

Between March and October there were two distinct algal blooms, corresponding to the two peaks in PUFAproduction. The earlier PUFA-peak was associated with the ice algal bloom in late April, and the later PUFApeak corresponded to the phytoplankton bloom just after ice break-up in early July (Figs 1 and 2). Omega3 fatty acids accounted for most of the PUFAs in both ice algae $(65 \%-74 \%)$ and phytoplankton (57\%-83\%) (Table 1, Appendix S4). Ice algae were present as early as March, but biomass began to build up in April and lasted until June. Similarly high biomass in terms of particulate carbon was found in April and June, but the

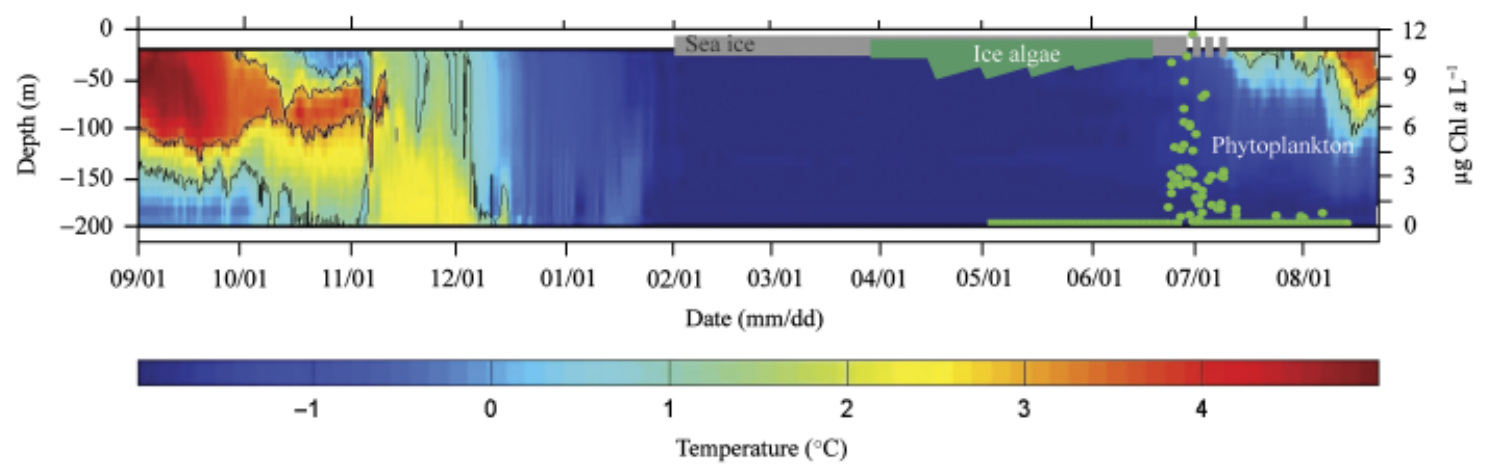

Fig. 1 The temperature profile measured from September 2006 to September 2007 in Rijpfjorden by a mooring equipped with temperature loggers spaced through the water column. Timing of sea ice and ice algae are indicated by drawings at the plot, whereas phytoplankton are chlorophyll $a(\mathrm{Chl} a)$ measurements from a fluorometer placed at the mooring at $17 \mathrm{~m}$ depth. Peak biomass of ice algae occurred from mid-April to approx. mid-June. The phytoplankton chlorophyll $a$ values are only approximate values due to lack of suitable water samples for proper calibration.

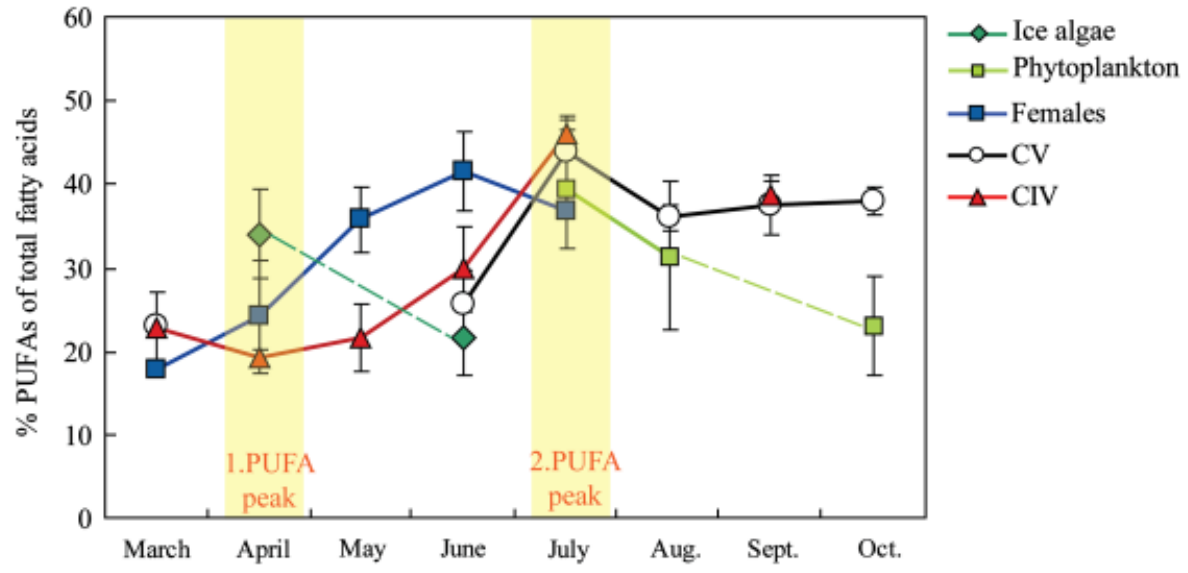

Fig. 2 The relative polyunsaturated fatty acids (PUFA) content (as percentage of total fatty acids; mean \pm SD) in algae and females, copepodite stage V (CV) and stage IV (CIV) of Calanus glacialis from March to October 2007 in Rijpfjorden. Only ice algae were present from April to June, whereas from July to October only phytoplankton was available for grazers. Hatched lines were drawn when data between monthly points were missing. For algae average values per month are shown, based upon three to five independent station measurements for ice algae (with three replicate ice cores each), and two to four stations with six sampling depths for phytoplankton. For C. glacialis average values based upon three to nine samples of 10-30 individuals per sample are shown per month. 
Table 1 Integrated (0-50 m) total carbon (C) and chlorophyll $a(\mathrm{Chl} a)$ biomass, and relative amount of polyunsaturated fatty acids (PUFAs) of total lipids and the relative amount of omega-3 fatty acids of total PUFAs (mean \pm SD; nd, not determined) in ice- and pelagic-particulate organic matter (POM) in Rijpfjorden 2007

\begin{tabular}{|c|c|c|c|c|}
\hline & Total C $\left(\mathrm{g} \mathrm{m}^{-2}\right)$ & $\mathrm{Chl} a\left(\mathrm{mg} \mathrm{m}^{-2}\right)$ & PUFAs/total lipids (\%) & Omega-3/PUFAs (\%) \\
\hline \multicolumn{5}{|l|}{ Ice-POM } \\
\hline April & $0.2 \pm 0.1$ & $22.4 \pm 15.3$ & $36.7 \pm 1.4$ & $65.0 \pm 1.5$ \\
\hline June & $0.2 \pm 0.1$ & $9.2 \pm 8.8$ & $22.3 \pm 2.8$ & $73.7 \pm 2.6$ \\
\hline \multicolumn{5}{|c|}{ Pelagic-POM } \\
\hline April & nd & $3.5 \pm 0.6$ & 14.3 & 56.5 \\
\hline June & $4.4 \pm 0.2^{*}$ & $15.9 \pm 2.2^{*}$ & $20.2 \pm 2.8^{*}$ & $75.9 \pm 1.1^{*}$ \\
\hline July & $21.6 \pm 4.8$ & $77.5 \pm 30.5$ & $40.3 \pm 3.1$ & $83.4 \pm 4.1$ \\
\hline August & $12.7 \pm 3.2$ & $12.7 \pm 3.2 \dagger$ & $32.5 \pm 4.5$ & $82.4 \pm 2.6$ \\
\hline October & $9.7 \pm 3.1$ & $23.1 \pm 9.1$ & $23.9 \pm 5.4$ & $80.4 \pm 3.1$ \\
\hline
\end{tabular}

${ }^{*}$ Mainly ice algae sloughed off from the bottom ice.

$\dagger$ Approximate values estimated from fluorometer readings.

Table 2 Calanus glacialis egg production measurements from Rijpfjorden in 2007

\begin{tabular}{lccccc}
\hline & $3-4$ March & $25-26$ April & 1-2 May & 5-6 June & 7-8 June \\
\hline Number of females incubated & 30 & 29 & 29 & 33 & 30 \\
Incubation temperature ( ${ }^{\circ}$ ) & -1.7 & -1.6 & -1.5 & 0 & 0.5 \\
Prosme length in mm (mean \pm SD) & $3.3 \pm 0.3$ & $3.4 \pm 0.3$ & $3.5 \pm 0.3$ & $3.5 \pm 0.2$ & $3.7 \pm 0.4$ \\
\% Egg laying females & 0 & 27.6 & 13.8 & 27.3 & 63.3 \\
Egg production day $^{-1}$ (mean \pm SE) & 0 & $7.4 \pm 2.8$ & $5.7 \pm 4.7$ & $14.8 \pm 5.2$ & $17.4 \pm 3.6$ \\
Max egg clutch size day $^{-1}$ & 0 & 16 & 15 & 46 & 59
\end{tabular}

*Per egg laying female.

ice algal PUFA content decreased from $37 \%$ in April to $22 \%$ in June ( $t$-test, $P=0.001$ ) (Table 1 , Fig. 2). The phytoplankton biomass was negligible during the icecovered period from February to June (Fig. 1). The ice break up in June/July was followed by a phytoplankton bloom in early July (Table 1, Fig. 1). The quality of the phytoplankton as food also peaked during this bloom when the phytoplankton contained up to $40 \%$ PUFAs (Table 1, Fig. 2). The pelagic POM (P-POM) had a low PUFA content in April (<15\%). In June, P-POM consisted primarily of ice algae sloughed off the bottom of the sea ice, so in June, ice algae and P-POM had a similar PUFA content $(t$-test, $P=0.667)$.

Secondary producers: C. glacialis

During April and May, females of C. glacialis had a pronounced increase in their relative PUFA content (Fig. 2; Appendix S5a). In contrast, CIV and CV individuals in these months had no significant increases in relative PUFA content (Fig. 2, Appendix S5b and c). C. glacialis females produced eggs during the ice algal bloom (Table 2), which mirrored an increase in egg abundance in the net samples from April to June (Fig. 3). We could not estimate egg production after June due to very low female abundance in this period
( $<1$ ind. $\mathrm{m}^{-3}$ in the upper $50 \mathrm{~m}$ ). Similarly, we found very low egg abundance from July to October (Fig. 3). The total lipid content in surface dwelling females dropped in April at the onset of spawning, but remained stable during the spawning period from April to June (Kruskal-Wallis median test, $P=0.0563$ ) (Fig. 5). In contrast, the total PUFA content in females slightly increased from March to June (Fig. 5).

The peak abundance of $C$. glacialis nauplii and young copepodites coincided with the pelagic bloom in July, which provided the offspring with excellent food (Figs 3 and 4). Young nauplii stages dominated during the icecovered period, whereas older feeding nauplii stages ( $\geq$ NIII) dominated at the onset of the phytoplankton bloom (Fig. 4b). In July, the youngest copepodite stages (CI-CIII) accounted for most of the population (70\%), whereas the overwintering stages CIV and CV dominated from August (Fig. 4a). Females (40\%-69\%) and CIV individuals $(17 \%-46 \%)$ were the most common $C$. glacialis stages from March to June, followed by CIV (17\%-46\%) (Fig. 4a). C. glacialis males were absent from March to September, but started to appear below $100 \mathrm{~m}$ depth $\left(0.5\right.$ ind. $\left.\mathrm{m}^{-3}\right)$ in October.

By early March, 23\% of the female population had already migrated to the upper $50 \mathrm{~m}$ (Fig. 5). In contrast, during the same time, only $1 \%$ of C. glacialis CIV 


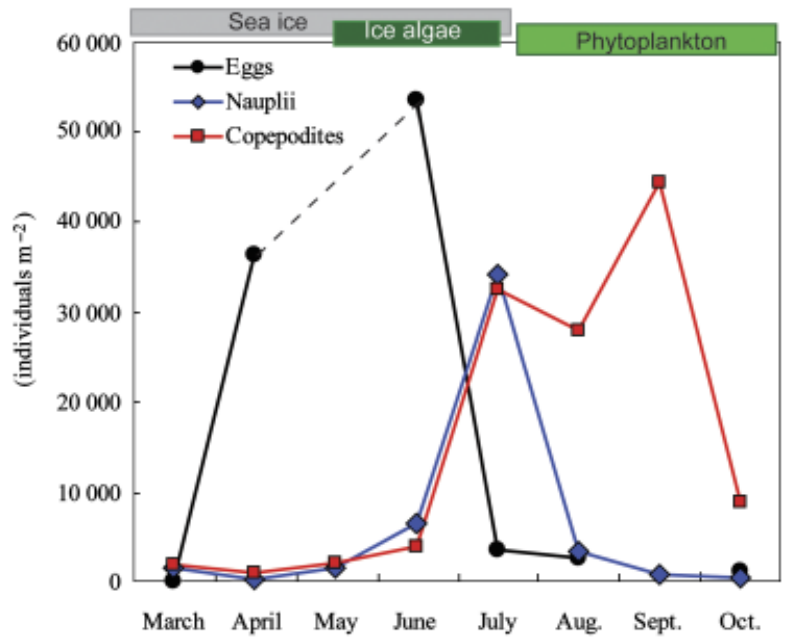

Fig. 3 Seasonal abundances of eggs, nauplii and copepodites of Calanus glacialis in Rijpfjorden 2007. Eggs collected with mesh size $63 \mu \mathrm{m}$ (hatched line from April to June since data from May is missing), whereas nauplii and copepodites were collected with mesh size $200 \mu \mathrm{m}$.

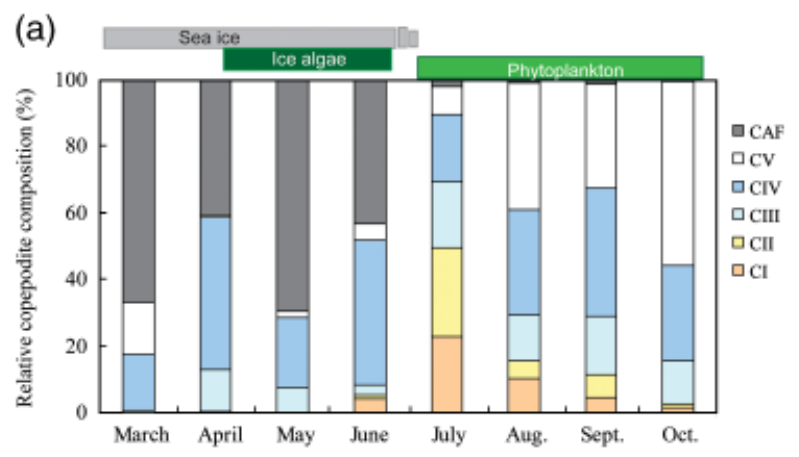

(b)

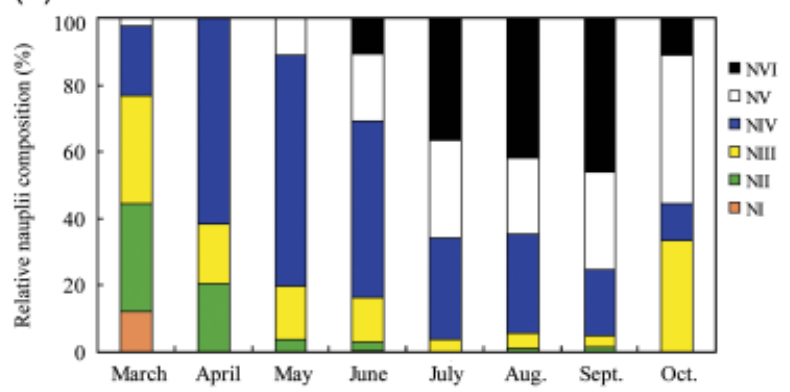

Fig. 4 Relative copepodite (a) and nauplii (b) composition of Calanus glacialis from March to October 2007 in Rijpfjorden (CAF; adult females).

individuals were present in surface waters. The seasonal descent started in August (data not shown), and by October, $<1.5 \%$ of the population remained in the upper $50 \mathrm{~m}$. The copepods that did remain at the

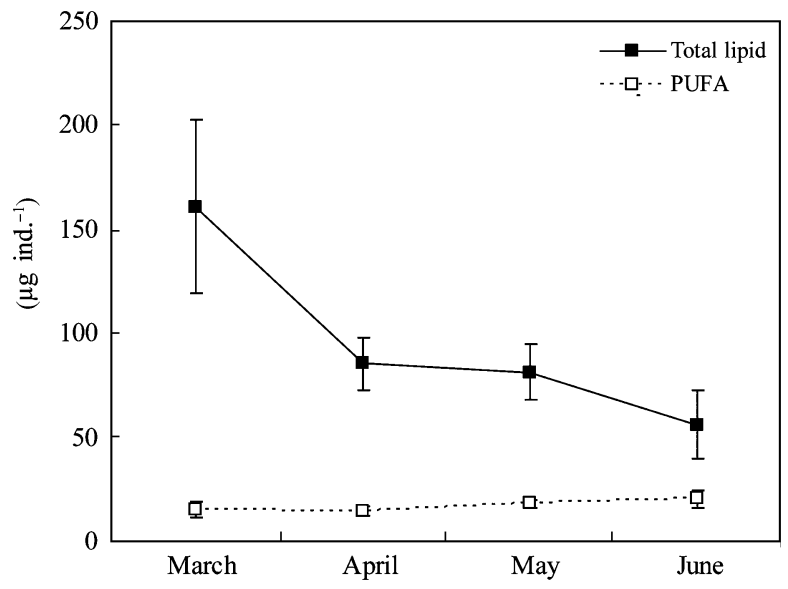

Fig. 5 Total lipids and polyunsaturated fatty acids (PUFAs) in surface dwelling $(0-50 \mathrm{~m}$ ) Calanus glacialis females (mean $\pm \mathrm{SD}$ ) from March to June 2007 in Rijpfjorden.

surface in October were almost entirely of young copepodites (CI-CIII). From August to October, CIV and CV specimens in the bottom layer were more lipid-rich than their counterparts in the surface (Fig. 6).

\section{Discussion}

Our findings show a close coupling between the solar cycle, onset of ice algae and phytoplankton blooms, and the reproductive success and growth of $C$. glacialis in a high Arctic ecosystem. More specifically, both the timing of the reproduction and the ontogenetic developmental time for $C$. glacialis are synchronized with the two distinct blooms of available high-quality algal food. C. glacialis females efficiently use the ice algae bloom as food for maturing and fueling early egg production. The progress of $C$. glacialis development then allows the offspring to take advantage of the second bloom of high-quality food produced by phytoplankton (Fig. 7a). As the Arctic ice cap shrinks and sea ice thins, the ice will break-up earlier in the season, resulting in an earlier onset of the pelagic bloom (Arrigo et al., 2008). However, the overall ice algal growth season will shorten as its onset is limited by light availability, which again is restricted by the low solar angle at high latitudes. Hence the onset of ice algal growth season will not be influenced by a thinner Arctic ice cap, but the end will be shifted forward following the earlier ice break-up. The time lag between the ice-associated and pelagic blooms will therefore shorten, resulting in a potential mismatch between the phytoplankton bloom and the temperature-controlled ontogenetic development of C. glacialis (Fig. 7b) (McLaren et al., 1988). 
(a)
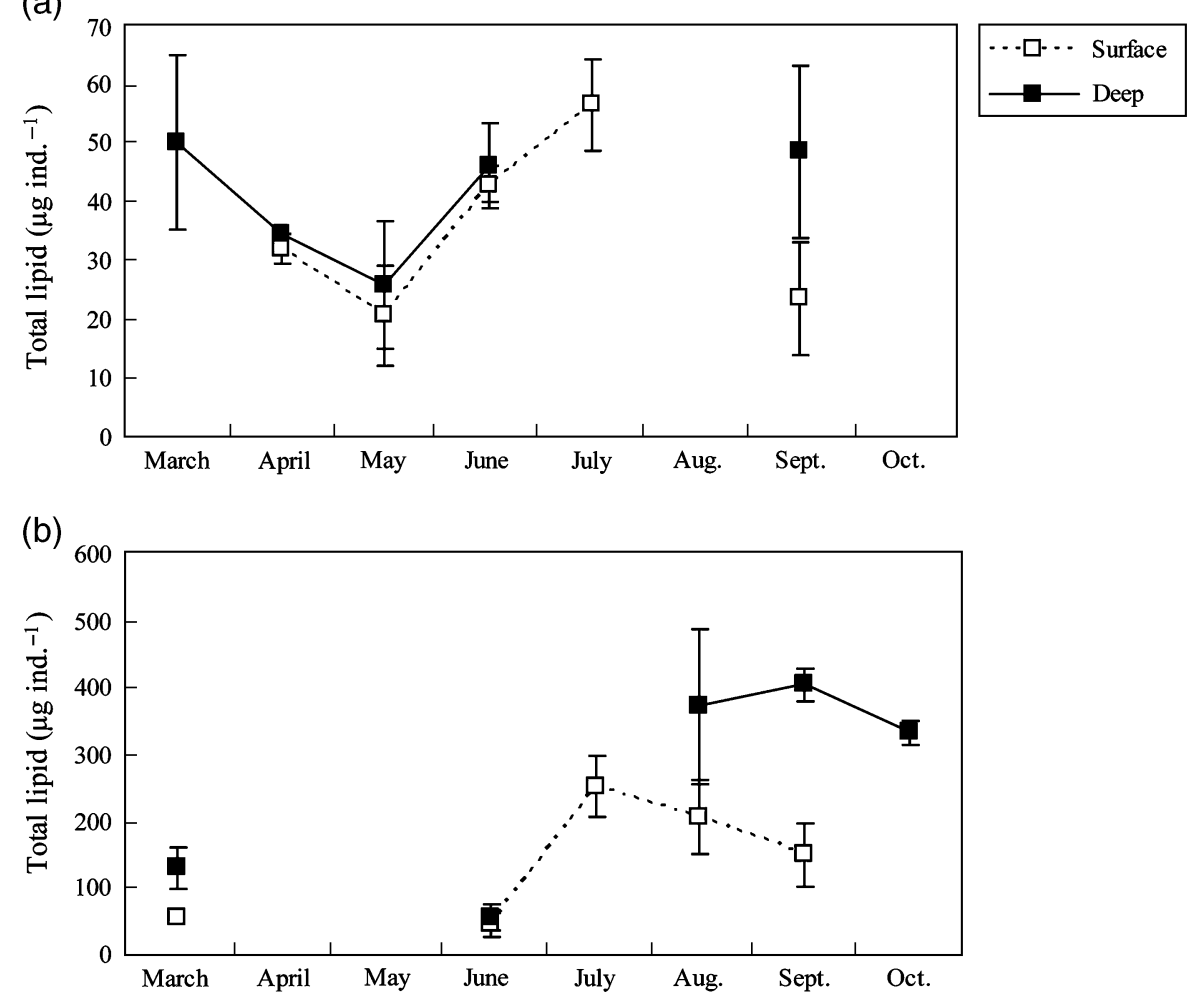

Fig. 6 Total lipid content (mean $\pm \mathrm{SD}$ ) in Calanus glacialis copepodite stage IV (CIV, a) and stage V (CV, b) in the upper $50 \mathrm{~m}$ (surface) and in the deep (100-140 m) from March to October 2007 in Rijpfjorden.

\section{Female reproduction}

The exact effect of food in C. glacialis maturation and reproduction remains unclear (Hirche \& Bohrer, 1987; Hirche, 1989; Hirche \& Kattner, 1993). It has been suggested that early reproduction in C. glacialis can be fueled by internal lipid reserves (Hirche \& Kattner, 1993), but there is no doubt that food speed up maturation (Tourangeau \& Runge, 1991) and increases egg production (Hirche, 1989; Hirche \& Kattner, 1993). Females of C. glacialis may need up to 4 weeks to mature, dependent on the food accessibility (Tourangeau \& Runge, 1991). C. glacialis can produce up to 90 eggs per day during bloom conditions (Melle \& Skjoldal, 1998), suggesting that we missed the peak egg production period when measuring the egg production rates in late April and June. During prebloom and late bloom conditions, the egg production rates of $C$. glacialis are highly variable (Melle \& Skjoldal, 1998) and comparable to the egg production rates we measured in April/May and June, respectively. Based on the prevailing sea water temperatures and the peak nauplii abundance, the peak egg production most likely occurred in late-May in Rijpfjorden 2007. C. glacialis needs about 3 weeks to develop to the first nauplii feeding stage (NIII) at temperatures below $-1{ }^{\circ} \mathrm{C}(\mathrm{M}$. Daase \& J. E. Søreide, unpublished results), suggesting that the total time from female maturation and spawning to when the new generation is ready to feed takes about 2 months. This timeline fits our monthly population data from Rijpfjorden and appears optimized for successful C. glacialis recruitment and growth, which is reflected in the high population biomass of $C$. glacialis in this fjord (Daase \& Eiane, 2007; Blachowiak-Samolyk et al., 2008; Søreide et al., 2008).

Particularly females took advantage of the ice algae bloom of high food quality. During the ice cover from February to June, both the fluorescence measurements and high nutrient levels (E. Leu, J. Wiktor, J.E. Søreide, J. Berge \& S. Falk-Petersen, unpublished results) indicated very low phytoplankton biomass and production. Active ice algae grazing in females were supported by a pronounced increase in PUFA content during the ice algal growth season and green guts already in April (field observations, not shown). The difference in female abundance - high during the ice algal bloom and few at the onset of the phytoplankton bloom - further supports the importance of the ice algae bloom for $C$. glacialis reproduction. Gonad maturation is energetically costly (Jonasdottir, 1999; Rey-Rassat et al., 2002; 
(a)

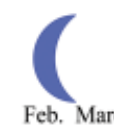

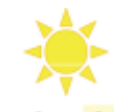

Jan. Feb. March April May June July Aug. Sept. Oct. Nov. Dec.

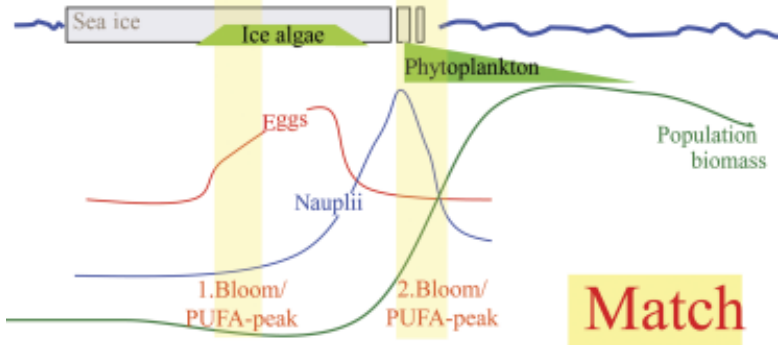

(b)

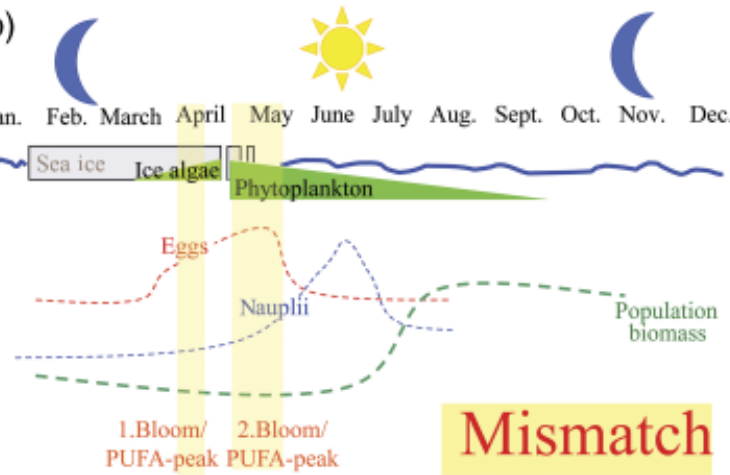

Fig. 7 Current primary production regime in Arctic shelf seas (a) with highest food quality [highest poly unsaturated fatty acid (PUFA) content] during the ice algal and phytoplankton blooms. Calanus glacialis efficiently uses the high-quality ice algal food in early spring to fuel reproduction, which allows the offspring (nauplii and copepodites) to fully exploit the high food quality in the later occurring phytoplankton bloom. This perfect primary producer-grazer match ensures high population biomass of $C$. glacialis. Future primary production regime (b) with shorter growth season for ice algae due to earlier ice break up, will lead to shorter time between the two PUFA-peaks associated with the ice algal and phytoplankton blooms. This decrease may lead to a mismatch between primary producers and the ontogenetic development of the offspring. Because $C$. glacialis requires roughly 3 weeks to develop to first feeding nauplii stage (NIII) after spawning, it may partially or totally miss the high-quality phytoplankton bloom during its most critical growth phase.

Lee et al., 2006). C. glacialis females can loose up to half of their lipid content during gonad maturation despite access to food (Hirche \& Kattner, 1993). After maturation is completed, however, the lipid content stabilizes since egg production is being driven by ingested food (Hirche \& Kattner, 1993). Although the lipid content in females from Rijpfjorden decreased and stabilized as descried above, the PUFA content remained constant or slightly increased during gonad development and egg formation (Fig. 5). This maintenance of PUFAs might reflect their role as essential structural units in membranes (Ackman, 1989). C. glacialis eggs have high proportions of both EPA (>17\%) and DHA (>13\%) (Hirche \& Kattner, 1993). As such, senescent diatoms with low PUFA content are poor food for copepods, resulting in lower egg production (Mayzaud et al., 1989; Jonasdottir, 1994; Breteler et al., 2005) and lower hatching success (Jonasdottir et al., 2005).

\section{Ontogenetic development}

Ice algae provided females high-quality food for early and successful reproduction. In turn, there was also high-quality food during nauplii and early copepodite development. Later in the season, the PUFA content of food may be less important because the overwintering stages CIV and CV that dominated at this time (Fig. 4a) mainly invested food into storage lipids (monounsaturated fatty acids and alcohols) for overwintering (Lee et al., 2006).

C. glacialis needs approximately 2 months to develop from $\mathrm{CI}$ to their overwintering stages CIV and CV at temperatures around $3{ }^{\circ} \mathrm{C}$ (Corkett et al., 1986). CI individuals started to appear in Rijfjorden in June and July, which corresponded to the dominance of CIV and $\mathrm{CV}$ in late August (Fig. 4a) and known sea water temperatures in the upper $50 \mathrm{~m}$ from July to August (Fig. 1). The earlier C. glacialis reaches its overwintering stage, the earlier it can accumulate lipids and descend to its overwintering depth, reducing the predation risk (Dale et al., 1999; Varpe et al., 2007). In October, CV dominated (55\%), followed by CIV (29\%), suggesting that $C$. glacialis completes its life cycle in 1-2 years despite the relative extreme environment in Rijpfjorden. In general, the C. glacialis life cycle is biennial north of the polar front and annual over the rest of its range (Conover, 1988). However, in Rijpfjorden, C. glacialis can take advantage of both ice algae and phytoplankton production and have optimized timing of reproduction and growth in accordance with the two bloom- and PUFA-peaks. This schedule ensured early reproduction and a long growth season for C. glacialis, allowing this Arctic population to complete its life cycle within 1 year.

\section{Concluding remarks}

C. glacialis elongated its grazing and growth season by efficient use of both the early ice algae and the late phytoplankton as food resources. The effects of a shorter ice algal growth season and a corresponding earlier onset of the phytoplankton bloom on the $C$. glacialis population remains unknown, and further research is required to examine the adaptability of $C$. glacialis under these future scenarios. However, based on this study and an earlier study (Tourangeau \& Runge, 1991), we propose that an earlier onset of the pelagic spring 
bloom will decrease the time between the two bloomand PUFA-peaks, since the onset of the ice algal bloom is mainly determined by the solar angle. This decrease may not only have a direct and negative influence on the reproduction, growth, and abundance of $C$. glacialis, but may also potentially affect the entire lipid-driven Arctic marine ecosystem. Many important predators in the Arctic ecosystem such as the little auk (Karnovsky et al., 2003; Steen et al., 2007) and the bowhead whale (Rogachev et al., 2008) depend on the small but very energy rich $C$. glacialis as their main prey.

The current dramatic reduction is sea ice thickness and coverage area may therefore have direct negative impacts on higher trophic levels, such as sea birds and large predators, since lipid-rich key Arctic grazers are likely to be replaced by temperate and less lipid-rich organisms (Falk-Petersen et al., 2007; Steen et al., 2007).

\section{Acknowledgements}

We thank H. Nygård, M. Vihtakari, J. Wiktor, J.-I. Karlsen, and L. A. Håhjem for their valuable help in the field. We also thank F. Cottier for help with the mooring data, D. O. Hessen for total particulate C data, J. Hovinen for zooplankton lipid analyses, and A. Weydmann and L. Samchyshyna for zooplankton analyses. This study was funded by the Norwegian Research Council (Project no. 178766/S30) as part of the Norwegian contribution to the International Polar Year (IPY) 2007-2009 and StatoilHydro.

\section{References}

Ackman RG (1989) Marine Biogenic Lipids, Fats, and Oils. CRC Press, Boca Raton, FL. Ambrose WG, Carroll ML, Greenacre M, Thorrold SR, McMahon KW (2006) Variation in Serripes groenlandicus (Bivalvia) growth in a Norwegian high-Arctic fjord: evidence for local- and large-scale climatic forcing. Global Change Biology, 12, $1595-1607$

Arrigo KR, van Dijken G, Pabi S (2008) Impact of a shrinking Arctic ice cover on marine primary production. Geophysical Research Letters, 35, doi: 10.1029/2008gl035028.

Berge J, Cottier F, Last KS et al. (2009) Diel vertical migration of Arctic zooplankton during the polar night. Biology Letters, 5, 69-72.

Blachowiak-Samolyk K, Søreide JE, Kwasniewski S, Sundfjord A, Hop H, FalkPetersen S, Hegseth EN (2008) Hydrodynamic control of mesozooplankton abundance and biomass in northern Svalbard waters (79-81 degrees N). Deep-Sea Research Part II Topical Studies in Oceanography, 55, 2210-2224.

Breteler WCMK, Schogt N, Rampen S (2005) Effect of diatom nutrient limitation on copepod development: role of essential lipids. Marine Ecology Progress Series, 291, 125-133.

Christie WW (1982) Lipid Analysis. Pergamon Press, New York.

Comiso JC, Parkinson CL, Gersten R, Stock L (2008) Accelerated decline in the Arctic Sea ice cover. Geophysical Research Letters, 35, doi: 10.1029/2007gl031972.

Conover RJ (1988) Comparative life histories in the genera Calanus and Neocalanus in high latitudes of the Northern Hemisphere. Hydrobiologia, 167, 127-142.

Corkett CJ, McLaren IA, Sevigny J-M (1986) The rearings of the marine calanoid copepods Calanus finmarchicus (Gunnerus), C. glacialis Jaschnov and C. hyperboreus Krøyer with comment on the equiproportional rule. Syllogeus, 58, 539-546.

Daase M, Eiane K (2007) Mesozooplankton distribution in northern Svalbard waters in relation to hydrography. Polar Biology, 30, 969-981.

Dale T, Bagoien E, Melle W, Kaartvedt S (1999) Can predator avoidance explain varying overwintering depth of Calanus in different oceanic water masses? Marine Ecology Progress Series, 179, 113-121.

Falk-Petersen S, Hopkins CCE, Sargent JR (1990) Trophic relationships in the pelagic, Arctic food web. In: Trophic Relationships in Marine Environments. Proceedings of the $24^{\text {th }}$ European Marine Biology Symposium, Oban, Scotland (eds Barnes M, Gibson RN), pp. 315-333. Aberdeen University Press, Oban, Scotland.

Falk-Petersen S, Mayzaud P, Kattner G, Sargent J (2009) Lipids and life strategy of Arctic Calanus. Marine Biology Research, 5, 18-39.

Falk-Petersen S, Timofeev S, Pavlov V, Sargent JR (2007) Climate variability and the effect on Arctic food chains. The role of Calanus. In: Arctic-Alpine Ecosystems and People in a Changing Environment (eds Ørbæk JR, Tombre T, Kallenborn R, Hegseth E, Falk-Petersen S, Hoel AH), pp. 147-166. Springer, Berlin.

Folch J, Lees M, Stanley GHS (1957) A simple method for isolation and purification of total lipids from animal tissues. Journal of Biological Chemistry, 226, 497-509.

Hegseth EN (1998) Primary production of the Northern Barents Sea. Polar Research, 17, 113-123.

Hirche HJ (1989) Egg production of the Arctic copepod Calanus glacialis - Laboratory experiments. Marine Biology, 103, 311-318.

Hirche HJ, Bohrer RN (1987) Reproduction of the Arctic copepod Calanus glacialis in Fram Strait. Marine Biology, 94, 11-17.

Hirche HJ, Kattner G (1993) Egg production and lipid content of Calanus glacialis in Spring - indication of a food dependent and food independent reproductive mode. Marine Biology, 117, 615-622.

Jonasdottir SH (1994) Effects of food quality on the reproductive success of Acartia tonsa and Acartia hudsonica - laboratory observations. Marine Biology, 121, $67-81$.

Jonasdottir SH (1999) Lipid content of Calanus finmarchicus during overwintering in the Faroe-Shetland Channel. Fisheries Oceanography, 61-72.

Jonasdottir SH, Trung NH, Hansen F, Gartner S (2005) Egg production and hatching success in the calanoid copepods Calanus helgolandicus and Calanus finmarchicus in the North Sea from March to September 2001. Journal of Plankton Research, 27, 12391259.

Jonasdottir SH, Visser AW, Jespersen C (2009) Assessing the role of food quality in the production and hatching of Temora longicornis eggs. Marine Ecology Progress Series, 382, 139-150.

Kaartvedt S (2008) Photoperiod may constrain the effect of global warming in arctic marine systems. Journal of Plankton Research, 30, 1203-1206.

Karnovsky NJ, Kwasniewski S, Weslawski JM, Walkusz W, Beszczynska-Moller A (2003) Foraging behavior of little auks in a heterogeneous environment. Marine Ecology Progress Series, 253, 289-303.

Kosobokova KN (1999) The reproductive cycle and life history of the Arctic copepod Calanus glacialis in the White Sea. Polar Biology, 22, 254-263.

Kwasniewski S, Hop H, Falk-Petersen S, Pedersen G (2003) Distribution of Calanus species in Kongsfjorden, a glacial fjord in Svalbard. Journal of Plankton Research, 25, $1-20$.

Lee RF, Hagen W, Kattner G (2006) Lipid storage in marine zooplankton. Marine Ecology Progress Series, 307, 273-306.

Mayzaud P, Chanut JP, Ackman RG (1989) Seasonal changes of the biochemical composition of marine particulate matter with special reference to fatty acids and sterols. Marine Ecology Progress Series, 56, 189-204.

McLaren IA, Sevigny JM, Corkett CJ (1988) Body sizes, development rates, and genome sizes among Calanus species. Hydrobiologia, 167, 275-284.

Melle W, Skjoldal HR (1998) Reproduction and development of Calanus finmarchicus, C. glacialis and C. hyperboreus in the Barents Sea. Marine Ecology Progress Series, 169, 211-228.

Pabi S, van Dijken GL, Arrigo KR (2008) Primary production in the Arctic Ocean, 19982006. Journal of Geophysical Research-Oceans, 113, 22.

Pond D, Harris R, Head R, Harbour D (1996) Environmental and nutritional factors determining seasonal variability in the fecundity and egg viability of Calanus helgolandicus in coastal waters off Plymouth, UK. Marine Ecology Progress Series, 143, 45-63.

Rey-Rassat C, Irigoien X, Harris R, Carlotti F (2002) Energetic cost of gonad development in Calanus finmarchicus and C. helgolandicus. Marine Ecology Progress Series, 238, 301-306.

Riediger ND, Othman RA, Suh M, Moghadasian MH (2009) A systemic review of the roles of n-3 fatty acids in health and disease. Journal of the American Dietetic Association, 109, 668-679.

Rogachev KA, Carmack EC, Foreman MGG (2008) Bowhead whales feed on plankton concentrated by estuarine and tidal currents in Academy Bay, Sea of Okhotsk. Continental Shelf Research, 28, 1811-1826.

Siegel S, Castellan NJ (1988) Non-Parametric Statistics for the Behavioral Sciences. McGraw-Hill, New York.

Smetacek V, Nicol S (2005) Polar ocean ecosystems in a changing world. Nature, 437, $362-368$. 
Søreide JE, Falk-Petersen S, Hegseth EN, Hop H, Carroll ML, Hobson KA, BlachowiakSamolyk K (2008) Seasonal feeding strategies of Calanus in the high-Arctic Svalbard region. Deep-Sea Research Part II Topical Studies in Oceanography, 55, 2225-2244.

Steen H, Vogedes D, Broms F, Falk-Petersen S, Berge J (2007) Little auks (Alle alle) breeding in a High Arctic fjord system: bimodal foraging strategies as a response to poor food quality? Polar Research, 26, 118-125.

Stroeve J, Holland MM, Meier W, Scambos T, Serreze M (2007) Arctic sea ice decline: faster than forecast. Geophysical Research Letters, 34, doi: 10.1029/2007gl029703.

Swadling KM, Nichols PD, Gibson JAE, Ritz DA (2000) Role of lipid in the life cycles of ice-dependent and ice-independent populations of the Copepod Paralabidocera antarctica. Marine Ecology Progress Series, 208, 171-182.

Tourangeau S, Runge JA (1991) Reproduction of Calanus glacialis under ice in spring in Southeastern Hudson Bay, Canada. Marine Biology, 108, 227-233.

Tremblay JE, Michel C, Hobson KA, Gosselin M, Price NM (2006) Bloom dynamics in early opening waters of the Arctic Ocean. Limnology and Oceanography, 51, 900-912.
Varpe O, Jorgensen C, Tarling GA, Fiksen O (2007) Early is better: seasonal egg fitness and timing of reproduction in a zooplankton life-history model. Oikos, 116, 13311342.

Wallace MI, Cottier FR, Berge J, Tarling GA, Griffiths C, Brierley AS (2010) Comparison of zooplankton vertical migration in an ice-free and a seasonally ice-covered Arctic fjord: an insight into the influence of sea ice cover on zooplankton behavior. Limnology and Oceanography, 55, 831-845.

Watanabe T, Tamiya T, Oka A, Hirata M, Kitajima C, Fujita S (1983) Improvement of dietary value of live foods for fish larvae by feeding them on omega- 3 highly unsaturated fatty-acids and fat-soluble vitamins. Bulletin of the Japanese Society of Scientific Fisheries, 49, 471-479.

Winer BJ, Brown DR, Michels KM (1991) Statistical Principles in Experimental Design. McGraw-Hill, New York.

Wright S, Jeffrey S (1997) High-resolution HPLC system for chlorophylls and carotenoids of marine phytoplankton. In: Phytoplankton Pigments in Oceanography (eds Jeffrey S, Mantoura R, Wright S), pp. 283-305. UNESCO, Paris.

\section{Supporting Information}

Additional Supporting Information may be found in the online version of this article:

Appendix S1. Rijpfjorden, the study area in north-eastern Svalbard with bathymetry indicated by different colour shadings. Appendix S2. Samples collected during 2007 in Rijpfjorden. Additional zooplankton samples were collected for lipid, dry weight and egg production measurements of $C$. glacialis.

Appendix S3. Photosynthetically active radiation $(400-700 \mathrm{~nm})$ in air measured in Rijpfjorden from February to October 2007. Monthly average values based on hourly measurements.

Appendix S4. The relative polyunsaturated fatty acid (PUFA) composition (mean \pm SD) in ice algae and phytoplankton, i.e. Ice- and Pelagic (P)- particulate organic matter (POM), in Rijpfjorden in 2007 (number of stations in brackets). All identified PUFAs are shown. The proportions of PUFA, monounsaturated fatty acids (MUFA) and saturated fatty acids (SAFA) of total lipids are also given.

Appendix S5. The relative polyunsaturated fatty acid (PUFA) composition (means \pm SD) in Calanus glacialis females (a), C. glacialis CV (b) and C. glacialis CIV (c) in Rijpfjorden in 2007 (number of samples in brackets). All identified PUFAs are shown. The proportions of PUFA, monounsaturated fatty acids (MUFA) and saturated fatty acids (SAFA) of total fatty acids (FA), and the absolute amounts of FA, fatty alcohols (Falc) and total lipids (TL) are also given. Samples collected in surface (0-50 m) and deep water $(>100 \mathrm{~m})$ are pooled which resulted in high variability in absolute values.

Please note: Wiley-Blackwell are not responsible for the content or functionality of any supporting materials supplied by the authors. Any queries (other than missing material) should be directed to the corresponding author for the article. 